\title{
Waterborne Viral Gastroenteritis: An Introduction to Common Agents
}

\author{
Parul Jain and Amita Jain
}

\begin{abstract}
Acute gastroenteritis is among the most common illnesses of human beings, and its associated morbidity and mortality are greatest among those at the extremes of age; children and elderly. During the 1970s, several viruses were associated with this syndrome, which are now known to be caused mainly by viruses belonging to four distinct families-rotaviruses, caliciviruses, astroviruses, and adenoviruses. Other viruses, such as the toroviruses, picobirnaviruses, coronavirus, and enterovirus 22, may play a role as well. Transmission by food or water has been documented for astroviruses, caliciviruses, rotaviruses, and norovirus. In developing countries, gastroenteritis is a common cause of death in children $<5$ years, while deaths from diarrhea are less common, much illness leads to hospitalization or doctor visits. Laboratory confirmation of waterborne illness is based on demonstration of virus particles or antigen in stool, detection of viral nucleic acid in stool, or demonstration of a rise in specific antibody to the virus. Newer methods for syndrome surveillance of acute viral gastroenteritis are being developed like multiplex real-time reverse transcriptase PCRs. Application of these more sensitive methods to detect and characterize individual agents is just beginning, but has already opened up new avenues to reassess their disease burden, examine their molecular epidemiology, and consider new directions for their prevention and control through vaccination, improvements in water quality, and sanitary practices.
\end{abstract}

P. Jain · A. Jain $(\square)$

Department of Microbiology, Virology Laboratory,

King George's Medical University,

Lucknow 226001 , India

e-mail: amita602002@yahoo.com

P. Jain

e-mail: parulkgmu@yahoo.com 


\section{Keywords}

Adenoviruses - Astroviruses Caliciviruses - Rotaviruses - Viral gastroenteritis · Waterborne infections

\section{Introduction}

Viral gastroenteritis resulting from exposure to contaminated drinking and recreational waters has been reported worldwide. Conservative estimates put diarrhea in the top five causes of deaths worldwide with 3.5 to 5 million deaths every year and most occurring in young children in nonindustrialized countries (Guerrant et al. 1990). According to the World Health Organization (WHO), diarrheal diseases account for $4.1 \%$ of the total DALY global burden of disease of which $88 \%$ is attributable to unsafe water supply, sanitation, and hygiene. Several waterborne outbreaks of viral gastroenteritis have been reported throughout the world, which may be of particular importance since these outbreaks have the potential to involve large numbers of people and wide geographic areas and, perhaps, to introduce new variants to an area. Here, we have briefly described the viral causes of diarrhea.

\section{Waterborne Outbreaks of Viral Gastroenteritis}

Waterborne viral gastroenteritis is defined as an illness that occurs after consumption or use of water intended for drinking. Contamination of underground water may occur as a result of leakage from septic tanks, flooding after heavy rainfalls, and back siphoning through a crossconnection between a well and a septic tank. Runoff water after heavy rainfall may contaminate surface water sources (Hedberg and Osterholm 1993). Human fecal wastes contain the viruses, and their numbers and distribution in sewagepolluted waters depend both on the burden of viral disease in the population and on the availability of municipal sewage treatment processing like filtration or chlorination of water supply.
Several outbreaks of viral gastroenteritis have been reported all around the world, associated with consumption of contaminated drinking water (Kukkula et al. 1997; Hafliger 2000) /ice (Cannon et al. 1991) /sea food like molluscan shellfish (Dowell et al. 1995; Rippey 1994).

\section{History of Viral Gastroenteritis}

Till 1970s, the etiology of gastroenteritis remained unknown in most of the cases. In 1972, Kapikian et al. (1972) first identified Norwalk virus, by immunoelectron microscopy, in stools of gastroenteritis cases after an outbreak that had occurred at an elementary school in Norwalk, Ohio, in October 1968. In 1973, rotavirus was identified in the duodenal mucosa of children with diarrhea by Bishop et al. using electron microscopy. Later, in 1975, astroviruses were described by Madeley and Cosgrove in the stools of infants hospitalized with diarrhea and in outbreaks of gastroenteritis in newborn nurseries (Madeley and Cosgrove 1975). Adenoviruses were first isolated from civilians and army recruits who had respiratory disease (Jones et al. 2005); the enteric adenoviruses were later implicated as a cause of acute diarrhea in children.

\section{Etiology}

Acute gastroenteritis is caused by a number of different agents, including bacteria, viruses, and parasites. Noroviruses (NoVs) and rotaviruses $(\mathrm{RVs})$ of group A are the leading causes of viral gastroenteritis. Sapoviruses $(\mathrm{SaVs})$, astroviruses $(\mathrm{AsVs})$, and enteric adenoviruses (AdVs) are other important causes. Candidate agents for whom etiologic relationship has not yet been confirmed are coronaviruses, picobirnaviruses, pestiviruses, toroviruses, and echovirus type 22 . 
Table 4.1 Features of causally confirmed human gastroenteritis viruses

\begin{tabular}{|c|c|c|c|c|c|}
\hline Virus & Family & Morphology & Genome & Clinical Severity & $\begin{array}{l}\text { Cultivation } \\
\text { possible }\end{array}$ \\
\hline $\begin{array}{l}\text { Rotavirus } \\
\text { (Group A) }\end{array}$ & Reoviridae & $\begin{array}{l}100 \mathrm{~nm} \text {, triple- } \\
\text { shelled, wheel- } \\
\text { like capsid }\end{array}$ & $\begin{array}{l}\text { Double- } \\
\text { stranded } \\
\text { segmented } \\
\text { RNA }\end{array}$ & $\begin{array}{l}\text { Major cause of severe } \\
\text { dehydrating diarrhea in } \\
\text { children }<5 \text { years of age }\end{array}$ & Yes \\
\hline Norovirus & Caliciviridae & $\begin{array}{l}27-40 \mathrm{~nm}, \\
\text { round virus }\end{array}$ & $\begin{array}{l}\text { Positive- } \\
\text { sense single- } \\
\text { stranded } \\
\text { RNA }\end{array}$ & $\begin{array}{l}\text { Epidemics of diarrhea and } \\
\text { vomiting in all ages }\end{array}$ & No \\
\hline Sapovirus & Caliciviridae & $\begin{array}{l}\text { Star of David } \\
\text { appearance }\end{array}$ & $\begin{array}{l}\text { Positive- } \\
\text { sense single- } \\
\text { stranded } \\
\text { RNA }\end{array}$ & $\begin{array}{l}\text { Gastroenteritis in children } \\
<5 \text { years of age }\end{array}$ & No \\
\hline $\begin{array}{l}\text { Enteric } \\
\text { Adenovirus } \\
\text { (Group F) }\end{array}$ & Adenoviridae & $\begin{array}{l}90 \mathrm{~nm}, \\
\text { icosahedral }\end{array}$ & $\begin{array}{l}\text { Double- } \\
\text { stranded } \\
\text { DNA }\end{array}$ & $\begin{array}{l}\text { Endemic diarrhea in } \\
\text { children }<5 \text { years of age }\end{array}$ & $\begin{array}{l}\text { Yes, } \\
\text { fastidious }\end{array}$ \\
\hline Astrovirus & Astroviridae & $\begin{array}{l}28-30 \mathrm{~nm} \text { with } \\
\text { characteristic } \\
\text { star on surface }\end{array}$ & $\begin{array}{l}\text { Positive- } \\
\text { sense single- } \\
\text { stranded } \\
\text { RNA }\end{array}$ & $\begin{array}{l}\text { Endemic diarrhea in } \\
\text { children, outbreaks possible, } \\
\text { role in HIV-related diarrhea }\end{array}$ & Yes \\
\hline
\end{tabular}

The morphologic and clinical features of causally confirmed gastroenteritis viruses are highlighted in Table 4.1.

\section{Epidemiology}

The incidence of bacterial and parasitic gastroenteritis is more in developing countries as compared to the developed world. This reflects difference in hygiene and sanitation and is therefore subject to control by public health measures. On the other hand, the agents of viral gastroenteritis that have other modes of transmission as well account for a greater proportion of gastroenteritis episodes in the industrialized world.

Endemic childhood gastroenteritis is caused mainly by rotavirus and, to a lesser extent, astrovirus, enteric adenovirus, and sapoviruses. Epidemic gastroenteritis is primarily caused by noroviruses though outbreaks due to rotavirus, astrovirus, and sapovirus have also been reported. The distribution of various viruses among cases of gastroenteritis is given in Table 4.2.

\section{Brief Description of Agents of Viral Gastroenteritis}

\section{Rotavirus}

Structure: The mature virions are about $100 \mathrm{~nm}$ in diameter, are nonenveloped, and possess a triple-layered icosahedral protein capsid composed of an outer layer, an intermediate layer, and an inner core layer. The capsid contains all enzymes for mRNA production. The genome consists of 11 segments of double-stranded RNA, each segment codes for at least one protein. The segmented genome allows genetic reassortment during dual infections of cells or susceptible hosts, producing reassortants of mixed parentage which is a source of viral diversity (Estates and Kapikian 2007) (Fig. 4.1).

The viral proteins, structural and nonstructural: Rotavirus has six structural proteins (VP1 to VP4, VP6, and VP7) and six nonstructural proteins (NSP1 to NSP6). The innermost protein shell consists of VP2, arranged in an icosahedral lattice. The VP1 polymerase and VP3 capping 
Table 4.2 Distribution of common viruses causing human gastroenteritis

\begin{tabular}{llll}
\hline & Brandt et al1983 & Nguyen 2007 & Li 2009 \\
\hline Place of study & Washington & Vietnam & Hong Kong \\
\hline Time period of study & $1974-1982$ & $2002-2003$ & January-August 2008 \\
\hline Population & Pediatric & Pediatric & Pediatric \\
\hline Norovirus & - & $5.5 \%$ & $23 \%$ \\
\hline Rotavirus & $34.5 \%$ & $67.4 \%$ & $28 \%$ \\
\hline Enteric Adenovirus & $4.7 \%$ & $3.2 \%$ & $3 \%$ \\
\hline Astrovirus & $-{ }^{a}$ & $0.6 \%$ & $0.6 \%$ \\
\hline Sapovirus & - & $0.8 \%$ & 0 \\
\hline Mixed viruses & $40.1 \%$ & $5.5 \%$ & $0.4 \%$ \\
\hline Unexplained viruses & $19.1 \%$ & & \\
\hline a These viruses were not known till 1982 & &
\end{tabular}

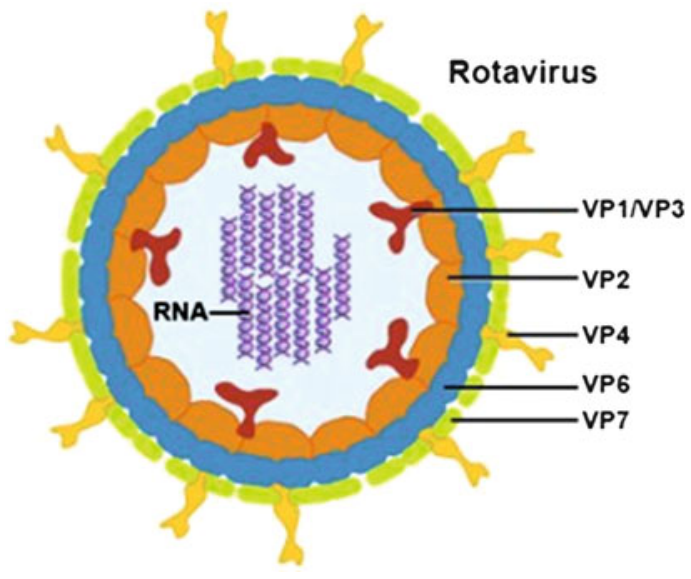

Fig. 4.1 Morphological structure of rotavirus showing location of various proteins

enzyme are anchored inside the VP2 shell. The middle layer consists of VP6, which forms thick trimeric pillars in an icosahedral lattice. VP6 is the target of the most abundant antibodies elicited by rotavirus infection, though this antigen is not exposed on the viral surface. The outermost layer consists of a coat glycoprotein VP7 and VP4 spikes, which protrude from the virion. (Estates and Kapikian 2007). The details of the proteins are shown in Table 4.3.

Classification: There are seven major groups of rotavirus (A through $\mathrm{G}$ ); group $\mathrm{A}$ and, to a lesser extent, group B and group $\mathrm{C}$ are primarily responsible for human gastroenteritis. Group specificity of rotaviruses is determined by the internal structural protein, viral protein 6 (VP6) which is the target of commercial immunoassays
(Tang et al. 1997). Within each group, rotaviruses are classified into serotypes on the basis of two outer capsid proteins, VP7 (G-protein/glycoprotein) and VP4 (P-protein/protease-sensitive protein) which induce neutralizing antibodies, on the basis of which a binary serotyping system has been developed. Till date, 15 VP7 or G serotypes have been identified. VP4 is a protease-cleaved protein, and serotypes determined by this protein are termed P serotypes. Due to a lack of readily available typing serum or monoclonal antibodies to different VP4 types, 26 different genotypes of VP4 have been identified based on sequence analysis of VP4. These genotypes correlate well with known serotypes, so the genotypes are mentioned in brackets (e.g., P1A[8]) (Estates and Kapikian 2007).

Replication cycle: Many aspects of replication cycle of rotavirus remain uncertain. The entire cycle occurs within the cytoplasm. The intestinal trypsin enzyme cleaves the rotavirus spike protein VP4 into an amino-terminal fragment, VP8, and a carboxy-terminal fragment, VP5. The VP8 fragment contains a hemagglutination domain, and the VP5 fragment contains a membrane interaction domain. Rotavirus enters the cells using several cell surface receptors. When intracellular calcium concentrations fall, rotavirus virions uncoat, forming double-layered subviral particle (DLP). DLPs are transcriptionally active particles composed of genome, VP1, VP3, and the inner two protein layers, which are assembled in viral factories 
Table 4.3 Characteristics of rotavirus structural and nonstructural proteins

\begin{tabular}{|c|c|c|c|c|c|}
\hline $\begin{array}{l}\text { Genome } \\
\text { segment }\end{array}$ & $\begin{array}{l}\text { Protein } \\
\text { product }\end{array}$ & $\begin{array}{l}\text { Mol. Wt. } \\
\text { of } \\
\text { protein } \\
\left(\mathrm{A}^{0}\right)\end{array}$ & $\begin{array}{l}\text { No. of } \\
\text { molecules } \\
\text { per virion }\end{array}$ & $\begin{array}{l}\text { Location in } \\
\text { virus } \\
\text { particles }\end{array}$ & Function \\
\hline 1 & VP1 & 125 & $<25$ & Core & $\begin{array}{l}\text { RNA-dependent RNA polymerase; part of } \\
\text { minimal replication complex }\end{array}$ \\
\hline 2 & VP2 & 94 & 120 & Core & $\begin{array}{l}\text { Inner capsid structural protein; sequence } \\
\text { nonspecific RNA binding activity; part of } \\
\text { minimal replication complex }\end{array}$ \\
\hline 3 & VP3 & 88 & $<25$ & Core & $\begin{array}{l}\text { Guanylyltransferase; methyltransferase; part } \\
\text { of virion transcription complex }\end{array}$ \\
\hline 4 & VP4 & 86.7 & 120 & $\begin{array}{l}\text { Outer capsid } \\
\text { spike }\end{array}$ & $\begin{array}{l}\text { Dimers form outer capsid spike; P-type } \\
\text { neutralization antigen, hemagglutination, } \\
\text { cell attachment protein, involved in } \\
\text { virulence; cleavage by trypsin into VP5 and } \\
\text { VP8 enhances infectivity }\end{array}$ \\
\hline 5 & NSP1 & 58.6 & 0 & Nonstructural & $\begin{array}{l}\text { Associates with cytoskeleton; extensive } \\
\text { sequence diversity between strains; two } \\
\text { conserved cystein-rich zinc finger motifs; } \\
\text { RNA binding }\end{array}$ \\
\hline 6 & VP6 & 44.8 & 780 & $\begin{array}{l}\text { Middle } \\
\text { capsid }\end{array}$ & $\begin{array}{l}\text { Major virion protein; middle capsid } \\
\text { structural protein; homotrimeric structure; } \\
\text { subgroup antigen; hydrophobic }\end{array}$ \\
\hline 7 & NSP3 & 34.6 & 0 & Nonstructural & $\begin{array}{l}\text { Homodimer, specifically binds } 3^{\prime} \text { end of } \\
\text { rotavirus mRNA; binds eIF4G1; involved in } \\
\text { translational regulation }\end{array}$ \\
\hline 8 & NSP2 & 36.7 & 0 & Nonstructural & $\begin{array}{l}\text { Nonspecific ssRNA binding; accumulates in } \\
\text { viroplasm; involved in viroplasm formation; } \\
\text { NT-Pase activity, homomultimer; binds } \\
\text { NSP5 and VP1 }\end{array}$ \\
\hline 9 & VP7 & 37.4 & 780 & Outer capsid & $\begin{array}{l}\text { G-type neutralization antigen, } \mathrm{N} \text {-linked } \\
\text { high-mannose glycosylation and trimming }\end{array}$ \\
\hline 10 & NSP4 & 20.2 & 0 & Nonstructural & $\begin{array}{l}\text { Enterotoxin, receptor for budding of DLP } \\
\text { through ER membrane; N-linked high- } \\
\text { mannose glycosylation; uncleaved signal } \\
\text { sequence, rough ER transmembrane } \\
\text { glycoprotein; modulates intracellular } \mathrm{Ca}^{2+}\end{array}$ \\
\hline \multirow[t]{2}{*}{11} & NSP5 & 21.7 & 0 & Nonstructural & $\begin{array}{l}\text { Interacts with NSP2 and NSP6; } \\
\text { homomultimerizes; autocatalytic kinase } \\
\text { activity; binds single-stranded RNA }\end{array}$ \\
\hline & NSP6 & 12 & 0 & Nonstructural & $\begin{array}{l}\text { Product of second out of frame ORF; } \\
\text { interacts with NSP5; localizes to viroplasm }\end{array}$ \\
\hline
\end{tabular}

Table adapted from Estes and Kapikian 2007, Feild's virology, 5th ed.

termed viroplasms. The dsRNA transcribes mRNA, the newly transcribed rotavirus mRNA enters two pools, mRNA that remains sequestered within viroplasms is replicated to produce negative-strand RNA which remains associated with the positive strand, while mRNA that escapes viroplasms is translated. The dsRNA segments formed within nascent subviral particles mature by budding through the membrane of the endoplasmic reticulum, when particles acquire their outer capsid proteins (Mendez et al. 1999) (Fig. 4.2).

Epidemiology: Worldwide, nearly all children are infected with rotavirus by $3-5$ years of age. In developing countries, the incidence of rotavirus diarrhea has varied between 0.07 and 
Fig. 4.2 Representation of rotavirus replication cycle in intestinal polarized cells

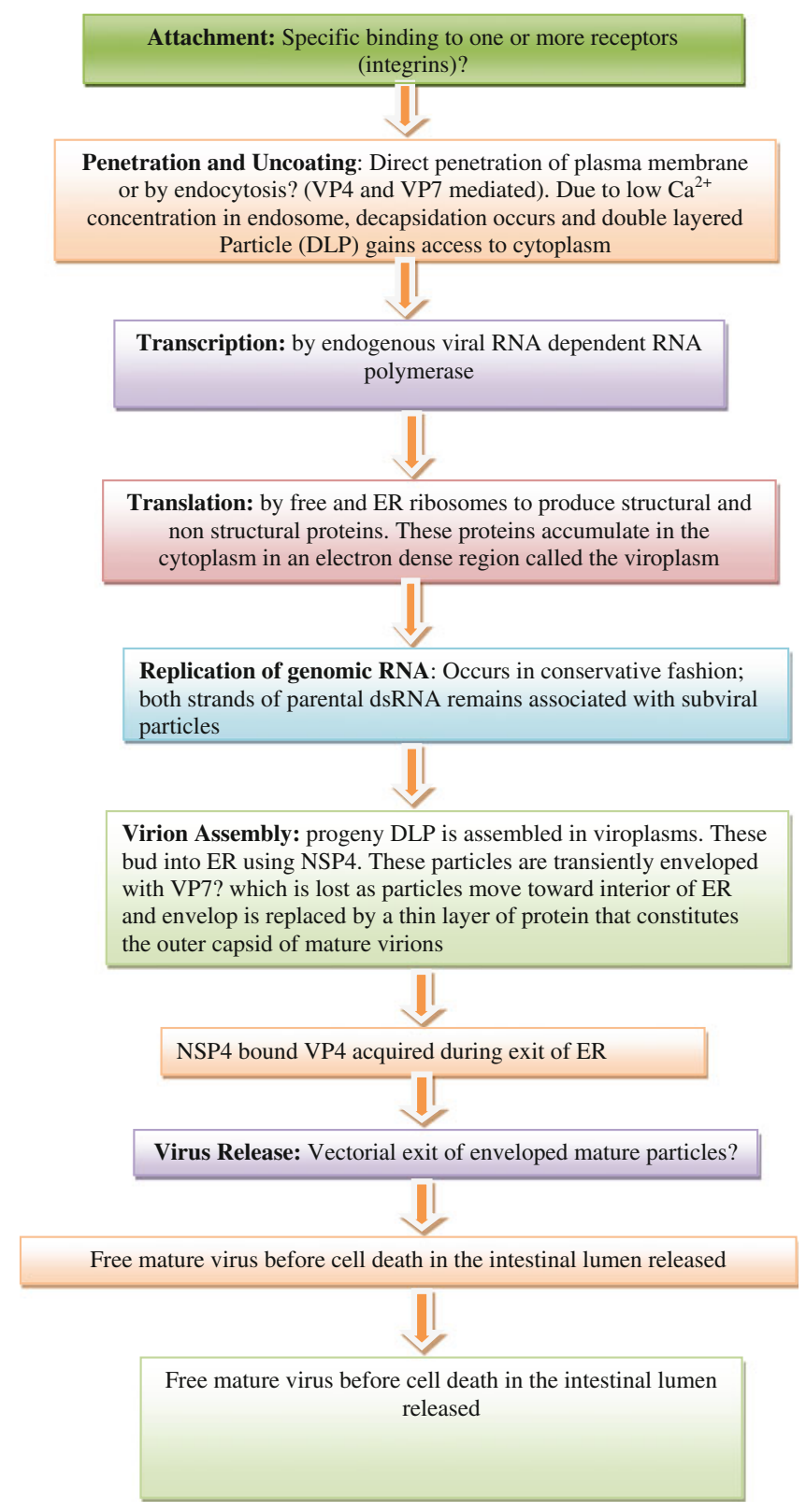

0.8 episodes per child per year (Bresee et al. 1999). The incidence is similar in developed countries, implying that this infection cannot be effectively controlled by improvement in sanitation and hygiene. Incidence of disease peaks among children 4 to 23 months of age, but illness in adults is also known. Neonatal infections are often asymptomatic because of protection from maternal immunity, while infections after 3 months of age are more likely to be symptomatic. Reinfections of rotavirus are common, but disease severity decreases with each repeat infection. Therefore, depending on the epidemiologic setting, the proportion of children with rotavirus diarrhea varies, for example, a median of $8 \%$ of all cases of diarrhea in the community, $28 \%$ of outpatient visits, and $34 \%$ of hospitalizations are accounted for by rotavirus infections (Bresee et al. 1999). 
The incidence of rotavirus serotypes has varied by geographic location and time. Gene segments that encode the G- and P-proteins can segregate independently. This gives rise to strains with at least 42 different $\mathrm{P}-\mathrm{G}$ serotype combinations. Of the different serotypes of group A rotavirus identified, only 5 types (G1 through G4 and G9) are common; recently, G8 strains have emerged as important strains in parts of Africa. The four predominant $\mathrm{P}-\mathrm{G}$ combinations, $\mathrm{P}[8] \mathrm{G} 1, \mathrm{P}[4] \mathrm{G} 2, \mathrm{P}[8] \mathrm{G} 3$, and $\mathrm{P}[8] \mathrm{G} 4$, comprise $88.5 \%$ of the strains worldwide (Santos and Hoshino 2005). Group B rotaviruses have been implicated in several large outbreaks of severe gastroenteritis among adults in China since 1982 (Hung 1988). It has also been found in adults and few children in Bangladesh (Sanekata 2003) and recently in western India (Kelkar and Zade 2004; Chitambar et al. 2011) but not in other parts of the world. Group $\mathrm{C}$ rotaviruses have been associated with a small proportion of pediatric cases in several countries worldwide (Oseto et al. 1993). Asian Rotavirus Surveillance Network (ARSN) performed the first phase of data collection in nine countries and regions over a 2-year period during 2001-2003, when it was known that rotavirus was responsible for overall $45 \%$ diarrhea admissions in the region. G1 was the commonest strain in Hong Kong (49\%) and Vietnam (47\%), G9 in Korea (39\%), Taiwan (37\%), and Thailand (55\%), while G3 was the commonest in China (67 \%) (Nelson et al. 2008).

In temperate climates, rotavirus disease occurs predominantly during the cooler fall and winter months, while in tropical areas, the infection occurs in an endemic fashion throughout the year.

Transmission: Rotaviruses are usually transmitted by the faeco-oral route, but speculation continues whether these are also transmitted by the respiratory route. The rapid spread of rotaviruses can be attributed to its ability to survive on various surfaces under different conditions (Wilde et al. 1992). Rotaviruses have been detected in both treated and untreated sewage water. The contaminated water may be an important source for group B rotavirus outbreaks though its role in transmission of group A viruses is unknown (Estates and Kapikian 2007).

Incubation period of rotavirus diarrhea has been estimated to be $<48 \mathrm{~h}$ though it varies from 1 to 4 days. Duration of virus excretion ranges from 4 to 57 days. In $43 \%$ of children, viral excretion stops in 10 days of onset of diarrhea, and in $70 \%$ of children, it stops within 20 days, while in $30 \%$ of children, virus may be detected in stool for 25-57 days.

Pathogenesis: In immunocompetent children, rotavirus infection is restricted to mature enterocytes in the villous epithelium of the proximal small intestine, which are ultimately destroyed.

Osmotic diarrhea results from malabsorption of carbohydrates due to reduction in absorptive villous epithelium as well as due to decreased turnover of microvillar membrane disaccharidases. Also, a role of NSP4 protein that functions as an enterotoxin and alters epithelial cell function and permeability has been described. Additionally, it is suggested that rotavirus induces fluid and electrolyte secretion by activation of enteric nervous system in the intestinal wall (Gilger et al. 1992) Fig. 4.3.

Clinical manifestations: Rotavirus gastroenteritis is more frequently associated with dehydration than is gastroenteritis by other pathogens. The clinical spectrum of rotavirus infection varies from subclinical illness to severe gastroenteritis and potentially fatal dehydration. The illness has an abrupt onset, with vomiting lasting 1-2 days, followed by loose, watery diarrhea that lasts for approximately 5 days, and the stools rarely contain red or white cells. Up to one-third of patients may have a temperature of $>39{ }^{\circ} \mathrm{C}$.

Respiratory and neurologic (Carlson et al. 1978) symptoms have been reported in children with rotavirus infection, but causal associations have not been proven. Diabetes mellitus, intussusceptions, sudden infant death syndrome, and necrotizing enterocolitis have also been reported with rotavirus infection.

In children with primary or acquired immunodeficiency (particularly bone marrow and liver transplant recipients), rotavirus can cause severe and prolonged disease with prolonged viral excretion and rarely can replicate extraintestinally. 


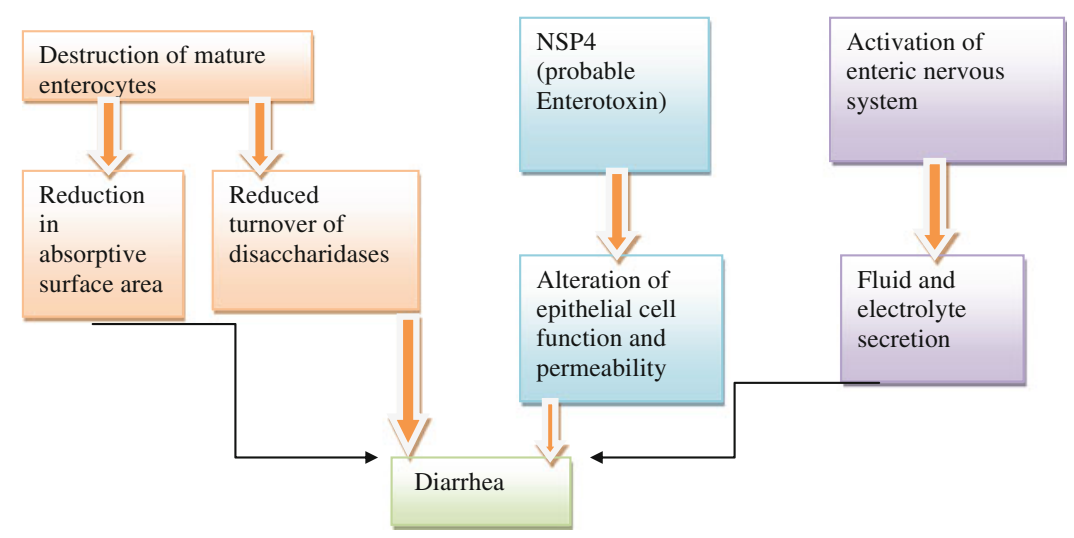

Fig. 4.3 Pathogenesis of rotavirus gastroenteritis

Immunity: Rotavirus-specific secretory $\operatorname{IgA}$ antibodies in the intestine appear only for a short duration during acute infection. These are correlated with a temporary protection against rotavirus disease, and therefore, reinfections with rotaviruses are common. During the acute phase, these antibodies are directed principally against VP2 and VP6 which broaden to include other proteins during the convalescent phase. Serum IgM antibodies also appear during the acute phase which is later replaced by $\operatorname{IgG}$ and, to a lesser extent, by $\operatorname{IgA}$ antibodies.

\section{Laboratory diagnosis:}

1) Virus Isolation: Human rotaviruses can be isolated in cell culture, although this is a slow and laborious process. The cell culture medium must be supplemented with proteases like trypsin or pancreatin. Cell lines in which rotaviruses can be isolated include primary simian kidney cells, intestinally derived cell lines like human colon adenocarcinoma cell line $\mathrm{CaCo}_{2}$, and MA104.

2) Direct examination by electron microscope: It is now not used routinely but can be of use for detecting nongroup A rotaviruses and mixed infections with other enteric viruses.

3) Antigen detection: Rotavirus immunoassays are predominantly based on ELISA or latex agglutination principles and use either monoclonal or polyclonal antibodies. The commercial ELISA kits can have a sensitivity and specificity of up to 98 and $100 \%$, respectively. Monoclonal G- and P-serotype-specific antibodies to rotaviruses are also commercially available in ELISA format to type the most frequent human rotavirus strains.

4) Nucleic Acid Detection:

a. Identification of dsRNA by RNA-PAGE: Viral RNA from a specimen can be directly subjected to polyacrylamide gel electrophoresis and then differentiated on the basis of characteristic patterns of bands by silver staining, referred to as electropherotypes. This is of limited potential today, but appearance of an unusual electropherotype could denote a novel strain or a nongroup A virus.

b. Dot Blot Assays: Viral RNA is extracted from patient specimen, spotted onto nitrocellulose membrane, and hybridized with radiolabeled cDNA probes.

c. PCR: It is the most sensitive method for detecting group A, B, and C rotaviruses. RTPCR can be done directly from stool samples and can also be used for P genotyping.

5) Serologic Assays: ELISA can be used to detect rotavirus-specific antibodies in stool and serum. Serum IgA detection is the most sensitive and rapid test for diagnosis of primary infection. A fourfold rise in convalescent-phase serum and stool samples IgA and IgG titers over acute-phase samples is also a reliable indicator of acute infection.

Treatment: Rotavirus disease spontaneously resolves within 1-2 weeks, but to prevent dehydration, appropriate therapy should be instituted early. In children who can take oral 
fluids, standard hydration solution recommended by the World Health Organization is the therapy of choice. If oral rehydration fails, if the patient is severely dehydrated or patient cannot tolerate oral fluids because of vomiting, intravenous fluids must be administered. Therapeutic role of probiotics, bismuth salicylate, and enkephalinase inhibitors like racecadotril is at present considered to be at an experimental stage. Antibiotics and antimotility agents should be avoided. Early refeeding after rehydration of children is recommended. In chronic symptomatic rotavirus infection in immunocompromised children, orally administered immunoglobulins or colostrums might be considered.

\section{Prevention:}

- Effective disinfection of contaminated material. A spray composed of $0.1 \%$ o-phenylphenol and $79 \%$ ethanol is an effective surface disinfectant for rotaviruses.

- Careful hand washing.

- Vaccine: The objective of rotavirus vaccine is to prevent moderate-to-severe disease but not mild disease associated with rotavirus, to duplicate the degree of protection that follows natural infection and to decrease the number of hospitalizations with dehydration, especially in resource-poor countries, where mortality associated with rotavirus is high. The different vaccines available/under development for rotaviruses are as under:

1. Vaccines based on animal rotaviruses: Considered to be naturally attenuated for humans, the Jennerian vaccines. Three monovalent animal rotavirus vaccines, two bovine rotavirus strains, RIT 4237 (P6[1]G6) and WC3 (P7[5]G6), and a simian (rhesus) rotavirus reassortant vaccine (RRV) strain (P[3]G3) have been studied. Variable efficacy was seen in field trials with these vaccines. China introduced live attenuated oral LLR vaccine that was derived from a lamb strain of rotavirus, the efficacy of which is not known (Dennehy 2008).

2. Human-rhesus RRV (RotaShield): This was the first multivalent live oral reassortant vaccine (a rhesus rotavirus tetravalent [RRVTV] vaccine), which contained a mixture of four most common $G$ serotypes, G1 to G4: three rhesus-human monoreassortant strains containing the VP7 genes of human serotypes G1, G2, and G4 strains were substituted for the VP7 gene of the parent RRV, and the fourth strain comprised serotype $\mathrm{G} 3$ of rhesus RRV (Kapikian 1996). This vaccine was licensed for use in the United States but was then withdrawn from the market because it was causally linked with intussusceptions with an estimated frequency of 1 in 10,000 vaccinated infants.

3. Currently licensed vaccines: Currently, two vaccines have been licensed for human use. First is a pentavalent human-bovine (WC3) reassortant live attenuated oral vaccine (RotaTeq) developed by Merck Research Co. Another is a live attenuated human rotavirus vaccine, strain $89-12$, that was originally developed from P1A[8]G1 by tissue culture passage of a wild-type human rotavirus isolate. GlaxoSmithKline Biologicals further modified the vaccine by cloning and tissue culture passaging of the parent 89-12 vaccine strain to develop the resulting vaccine, RIX4414 (Rotarix). Salient features of these two vaccines are shown in Table 4.4.

4. Candidate Vaccines: The National Institute of Allergy and Infectious Diseases (NIAID) has developed a tetravalent human-bovine rotavirus reassortant vaccine candidate, which incorporates four reassortants with VP7 specificity for G1, G2, G3, and G4 human serotype and 10 genes from the bovine rotavirus UK strain (P[7]G6). This vaccine showed safety and efficacy in a clinical trial at Finland (Midthun et al. 1985).

Live, orally administered neonatal human rotavirus strains have been explored as vaccine candidates because they appear to be naturally attenuated. Two naturally occurring humanbovine rotavirus reassortants obtained from asymptomatically infected newborns in Delhi (116E) and Bangalore (I321) have undergone clinical trials. The former has 10 human rotavirus genes and a single gene segment encoding VP4 derived from a bovine rotavirus, whereas the latter has two human rotavirus nonstructural genes and nine bovine rotavirus genes (Glass 
Table 4.4 Features of currently licensed vaccines

\begin{tabular}{|c|c|c|c|c|c|}
\hline Vaccine & $\begin{array}{l}\text { Parent } \\
\text { strain and } \\
\text { genotype }\end{array}$ & Formulation & Dose & Side effects & $\begin{array}{l}\text { Protective } \\
\text { efficacy }\end{array}$ \\
\hline $\begin{array}{l}\text { Rota } \\
\text { Teq }\end{array}$ & $\begin{array}{l}\text { Bovine } \\
\text { rotavirus } \\
\text { strain } \\
\text { WC3, } \\
\text { P7[5]G6 }\end{array}$ & $\begin{array}{l}5 \text { reassortants; } 4 \text { reassortants } \\
\text { with the VP7 specificity for } \\
\text { serotype } 1,2,3 \text {, or } 4 \text {, and } 1 \\
\text { reassortant with the VP4 of } \\
\text { P1A[8] specificity from the } \\
\text { human rotavirus parent strain } \\
\text { with the remainder of the genes } \\
\text { from the WC3 bovine rotavirus } \\
\text { parent }\end{array}$ & $\begin{array}{l}3 \text { oral } \\
\text { doses at } 2, \\
4, \text { and } \\
6 \text { months } \\
\text { of age }\end{array}$ & $\begin{array}{l}\text { Intussusceptions } \\
\text { not seen. } \\
\text { Diarrhea and } \\
\text { vomiting may } \\
\text { occur }\end{array}$ & $\begin{array}{l}84.7 \% \\
\text { against } \\
\text { severe } \\
\text { gastroenteritis } \\
\text { and } \\
\text { hospitalization }\end{array}$ \\
\hline Rotarix & $\begin{array}{l}\text { Human } \\
\text { rotavirus } \\
\text { strain } 89- \\
12, \mathrm{G} 1 \\
\mathrm{P} 1 \mathrm{~A}[8]\end{array}$ & $\begin{array}{l}\text { No reassortants; attenuation by } \\
\text { passage of human rotavirus } 89- \\
12 \text { strain in tissue culture }\end{array}$ & $\begin{array}{l}2 \text { oral } \\
\text { doses at } 2 \\
\text { and } \\
4 \text { months } \\
\text { of age }\end{array}$ & $\begin{array}{l}\text { Intussusceptions } \\
\text { not seen. } \\
\text { Diarrhea and } \\
\text { vomiting may } \\
\text { occur }\end{array}$ & $\begin{array}{l}89 \% \text { against } \\
\text { all rotavirus } \\
\text { disease }\end{array}$ \\
\hline
\end{tabular}

2005). A human neonatal $\mathrm{P}[6] \mathrm{G} 3$ strain, RV3, was evaluated as an oral vaccine in 3-month-old infants and was found to be safe and well tolerated (Barnes et al. 2002).

\section{Norwalk and Related Human Caliciviruses}

History: An outbreak of acute gastroenteritis occurred among students and teachers in a school in Norwalk, Ohio, in 1968, with a primary attack rate of $50 \%$ and secondary attack rate of $32 \%$ (Adler and Zickl 1969). A similar illness occurred when organism-free filtrates of stools collected from affected individuals were given to human volunteers. But the agent could not be grown in cell culture and organ culture (Blacklow et al. 1972). In 1972, Kapikian et al. (1972) by using immunoelectron microscopy (IEM) identified the Norwalk virus in a fecal filtrate used to induce illness in human volunteers which were seen as $27 \mathrm{~nm}$ viral particles. Also, convalescent-phase serum was collected from a volunteer who became ill following inoculation with the fecal filtrate. Using an antigen-antibody reaction, the virus particles were precipitated and the complexes were visualized with an electron microscope.

All these data were compiled, and Norwalk virus (NV) was proposed to be the etiologic agent of the Norwalk, Ohio, outbreak of gastroenteritis. Other small, round-structured viruses (SRSVs) that were morphologically similar to $\mathrm{NV}$ were later associated with outbreaks of gastroenteritis (Dolin 1982; Thornhill 1977).

Classification: Initially, the acute gastroenteritis viruses were classified on the basis of morphology. For example, NV was the prototype of a group of agents initially called small round-structured viruses (SRSVs). Later, based on molecular biology, most SRSVs were placed in the family Caliciviridae. Family Caliciviridae is now divided into four genera-Norovirus, Sapovirus, Lagovirus, and Vesivirus. Within each genus, species have been defined based on genetic relatedness. For species Norwalk virus (genus Norovirus) and species Sapporo virus (genus Sapovirus), based on relatedness of VP1, capsid protein genogroups have been proposed which are further classified into genotypes (Atmar and Estes 2001) (Table 4.5). The noroviruses have been subdivided into at least five genogroups designated GI-GV (Lew et al. 1994), most common strains implicated in human disease fall into genogroups GI and GII (Patel et al. 2009). The GI genogroup includes the Norwalk virus, whereas the Snow Mountain and Hawaii viruses belong to genogroup GII. Individual strains are designated by Arabic numeral after the genogroup designation: for example, GI.1 (Norwalk) or GII.1 (Hawaii). 
Table 4.5 Genogroups and genotypes of Caliciviridae

\begin{tabular}{llcc}
\hline Genus & Species & Genogroups & Genotypes \\
\hline Norovirus (NoV) & Norwalk virus (NV) & I & 8 \\
\hline & & II & 19 \\
\hline & & III & 3 \\
\hline Sapovirus $(\mathrm{SaV})$ & & IV & 1 \\
\hline & Sapporo virus (SV) & V & 1 \\
\hline & & I & 3 \\
\hline & & II & 3 \\
\hline
\end{tabular}

Structure: The Calicivirus virions exhibit icosahedral symmetry. The virions have a single major capsid protein folding into 90 dimers to form a shell domain from which capsomeres protrude that are arch like. These arches are arranged in a way that 32 cup-shaped depressions are visible by electron microscopy, from where the caliciviruses derive their name (Latin: calyx means cup). The Norwalk virus, prototype of calicivirus is nonenveloped, small $(27-40 \mathrm{~nm})$, and round virus (Prasad and Rothnagel 1994).

Caliciviruses have a linear, single-stranded, positive-sense RNA genome (ranging from 7.3 to $8.5 \mathrm{~kb}$ in length) that is organized into two or more ORFs, depending on the genus. All caliciviruses encode a relatively small ORF near the $3^{\prime}$ end that encodes the minor structural protein, VP2. The nonstructural proteins are encoded toward the $5^{\prime}$ region in ORF one and the structural proteins toward the $3^{\prime}$ end of genome. The norovirus and vesivirus have separate ORFs (ORF2) for VP, whereas in sapovirus and lagovirus, the first ORF codes for the nonstructural proteins as well as the capsid protein, which is found in-frame at the end of the nonstructural proteins (Fig. 4.4).

Viral proteins: Structural: Caliciviruses have three structural proteins, the features of which are listed in Table 4.6. Nonstructural: Caliciviruses derive their mature nonstructural proteins by proteolytic cleavage of a large polyprotein encoded in ORF1 that has the viral RNA polymerase (NS7), helicase (NS3), and protease functions (NS6) (Jiang et al. 1993). The norovirus and vesivirus have five cleavage sites to produce six mature proteins (NS1 to NS6), while lagovirus and sapovirus have six cleavage sites to produce seven mature proteins (NS1 to NS7). The function of rest of the nonstructural proteins is unknown. Replication cycle is not fully known. Proposed replication cycle is shown in Fig 4.5.

Epidemiology: Noroviruses and sapoviruses have a worldwide distribution. Infections occur round the year, although the incidence tends to
Fig. 4.4 Genome of Norwalk virus

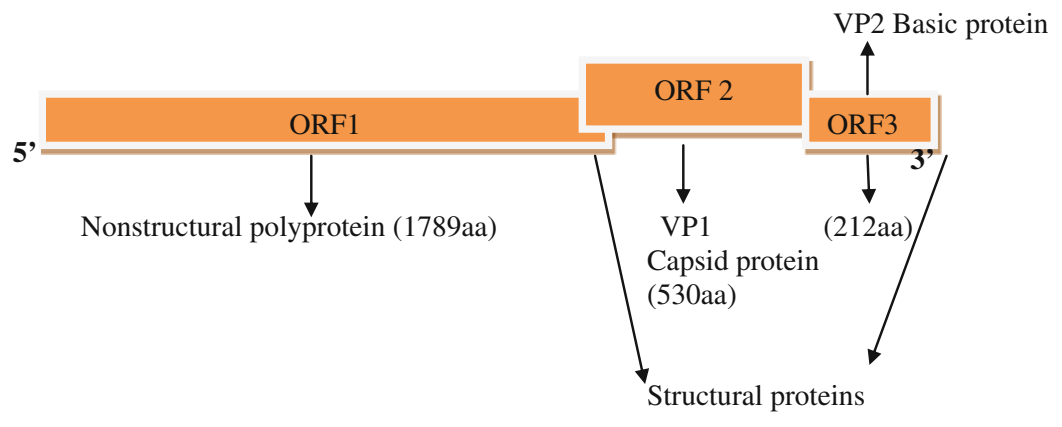


Table 4.6 Structural proteins of Norwalk virus

\begin{tabular}{lllll}
\hline $\begin{array}{l}\text { Protein } \\
\text { Product }\end{array}$ & $\begin{array}{l}\text { Mol. Wt. of } \\
\text { protein }(\mathrm{d})\end{array}$ & $\begin{array}{l}\text { No. of } \\
\text { molecules per } \\
\text { virion }\end{array}$ & $\begin{array}{l}\text { Location in } \\
\text { Virus } \\
\text { particles }\end{array}$ & Function \\
\hline VP1 & 60,000 & 180 & Capsid & $\begin{array}{l}\text { Major structural protein, determines antigenic } \\
\text { phenotype and interactions of virus with host } \\
\text { cells }\end{array}$ \\
\hline VP2 & $12,000-29,000$ & $1-2$ & Capsid & $\begin{array}{l}\text { Minor structural protein, function unknown, may } \\
\text { play a role in particle maturation and stability }\end{array}$ \\
\hline VPg & - & $1-2$ & Capsid & $\begin{array}{l}\text { Minor component, likely functions as a } \\
\text { nonstructural protein during replication }\end{array}$ \\
\hline
\end{tabular}

Fig. 4.5 Representation of proposed replication cycle of caliciviruses peak during cold weather months in temperate climates. Noroviruses have been associated with infection in all age groups, although most gastroenteritis outbreaks involve mainly older school-aged children and adults. In pediatric populations, importance of noroviruses may be second to that of rotaviruses. Sapoviruses on the other hand are primarily associated with pediatric gastroenteritis, which rarely needs hospitalization. A few outbreaks have been documented due to sapoviruses. Noroviruses are the single most important cause of gastroenteritis outbreaks and account for more than $90 \%$ of outbreaks of viral gastroenteritis and for about $50 \%$ of all-cause outbreaks worldwide (Patel et al. 2009). Epidemics occur round the year, in all age groups and in a variety of settings like schools, camps, nursing homes, swimming facilities, and restaurants (Table 4.7).

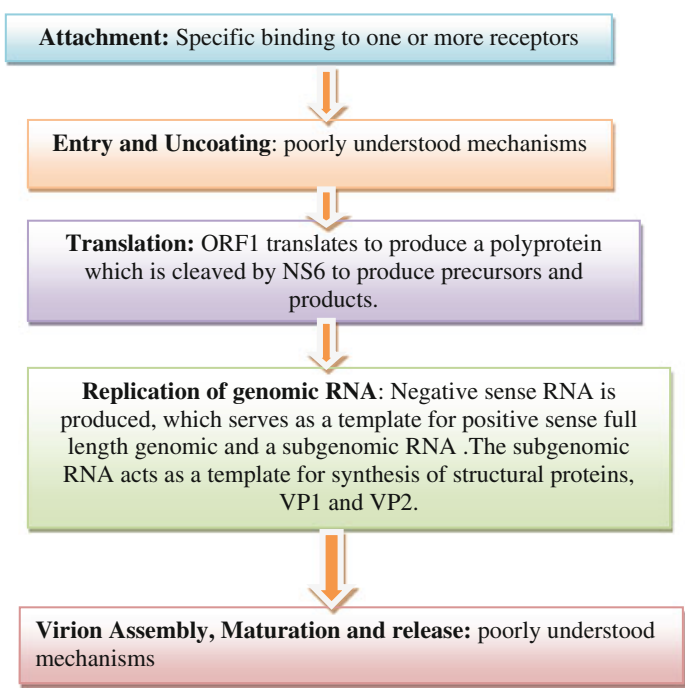

Transmission of calicivirus occurs predominantly by the faeco-oral route, though vomitus (Chadwick and McCann 1999) has also been implicated as a vehicle of transmission. The predominant modes of spread are person-toperson contact and food- or waterborne spread. Aerosolization and contamination of surfaces by infected individuals can also lead to exposure.

Incubation periods are generally $24-48 \mathrm{~h}$, though it ranges from 18 to $72 \mathrm{~h}$. Virus shedding in stools is maximal over the first 24-48 $\mathrm{h}$ after illness. Virus can be rarely detected beyond $72 \mathrm{~h}$ after the onset of vomiting or diarrhea by immunoelectron microscopy. However, virus can be detected for up to 3 weeks after resolution of illness using sensitive enzyme-linked immunosorbent assay techniques (Graham et al. 1994) or PCR (Okhuysen 1995). Virus may also be shed by asymptomatically infected individuals. 
Table 4.7 Epidemiology of Norwalk virus outbreaks

\begin{tabular}{llll}
\hline & Vega et al. (2011) & Lopman et al. (2003) & $\begin{array}{l}\text { Werber et al. } \\
(2009)\end{array}$ \\
\hline Study period & March 2009-January 2011 & $1995-2000$ & $\begin{array}{l}\text { 24 August-7 } \\
\text { September 2008 }\end{array}$ \\
\hline Place of study & $\begin{array}{l}\text { 20 state and local health } \\
\text { laboratories, United States }\end{array}$ & $\begin{array}{l}\text { 10 surveillance systems in } \\
\text { Europe network }\end{array}$ & Podgorica, Europe \\
\hline $\begin{array}{l}\text { Incidence of Norwalk } \\
\text { gastroenteritis (\%) }\end{array}$ & 72 & $>85$ & 60 \\
\hline Major serotype isolated & G2 & Not Known & G2 \& G1 \\
\hline New variants isolated & G2.4 New Orleans & Not Known & None isolated \\
\hline
\end{tabular}

GII.4 cluster is the predominant virus detected throughout the world. But major shifts in the predominant circulating strain can occur. Mixed infections of noroviruses within the same individual or within the same outbreak have been detected, which may allow recombination between RNA genomes and may lead to genetic diversity.

Pathogenesis: Reversible histopathologic lesions appear in the small intestine within $24 \mathrm{~h}$ after virus challenge like broadening and blunting of villi, shortening of microvilli, vacuolization of the lining epithelium, crypt hyperplasia, and infiltration of lamina propria by lymphocytes and polymorphs. These changes are present during illness and persist for a variable period of time after the illness. The histopathologic changes generally clear within 2 weeks after the onset of illness, although some jejunal changes can be noticed as late as 6 weeks after challenge. Diarrhea induced by the Norwalk virus is associated with a transient malabsorption of D-xylose and fat and with decreased levels of brush border enzymes, including alkaline phosphatase and trehalase. Susceptibility to infection with certain norovirus strains has also been associated with the presence of $\mathrm{H}$ blood group carbohydrate antigens, which are also expressed in gastrointestinal epithelial cells (Hutson et al. 2002). Nausea and vomiting may be contributed to delayed gastric motor function.

Clinical features: The calicivirus gastroenteritis is generally mild and self-limiting that usually lasts 24-48 h, though prolonged infection may be seen in immune-compromised individuals. After an incubation period of around $24 \mathrm{~h}$, the disease has a sudden onset with nausea, vomiting, diarrhea, abdominal cramps, fever, headache, chills, myalgia, or sore throat. Vomiting is more prevalent than diarrhea in children, whereas reverse is true in adults. The stools are typically loose and watery and do not contain mucus and leukocytes or red blood cells. Severe dehydration may occur in predisposed individuals like elderly patients with debilitating health conditions.

Immunity: Studies in human volunteers have shown that there are two forms of immunity to noroviruses: one is short term and the other is long term. Short-term immunity is protective, that is, serotype specific and protects against the infecting strain. While long-term immunity deviates from the traditional pattern; persons with higher levels of pre-existing antibody to $\mathrm{NV}$ are more susceptible to illness. Specific $\mathrm{ABO}$, Lewis, and secretor blood group phenotypes may also influence susceptibility to NV.

Laboratory diagnosis: Currently available diagnostic tools cannot detect all the caliciviruses in single, because of genetic and antigenic diversity. The various tools available are as follows:

1. Electron Microscopy: It is of limited value in routine diagnosis of $\mathrm{NV}$ because particles are usually present in low concentration and may be difficult to distinguish from other round, small objects present in stool. Also, the timings of stool collection are important; samples that are collected within $72 \mathrm{~h}$ of onset of diarrhea have the greatest yield. The sapoviruses are easier to detect; these have a Star of David appearance, that is, a six-pointed star with a dark hollow in the center. 
2. Immunoassays: Human calicivirus recombinant virus like particles rVLPs has been produced by expression of capsid proteins in baculovirus vectors. Hyperimmune antisera and now monoclonal antibodies are prepared against these VLPs which are employed in the development of ELISAs that can detect viral antigens in clinical specimens. Few diagnostic kits are commercially available.

3. RT-PCR: This is the most widely used technique for the detection of noroviruses in clinical samples like feces or vomitus, and contaminated food, water, or fomites. Quantitative real-time PCR has gained importance because it allows rapid detection as well as comparison of viral RNA levels.

Treatment: Not generally required because the disease is self-limited. Symptomatic treatment of headache, myalgias, and nausea with analgesics and antiemetics may provide relief. If severe dehydration develops, oral or intravenous therapy is indicated. Bismuth subsalicylate, loperamide, anticholinergic agents, adsorbents, or lactobacillus containing compounds are not recommended.

\section{Prevention:}

1. Outbreak prevention: Outbreak prevention should be situation specific, such as control of contamination of food and water, reduction in person-person spread by frequent hand washing, and effective environmental decontamination with disinfectants like hypochlorite at 5,000 ppm, hydrogen peroxide-based cleaners, and phenolic-based cleaners.

2. Vaccines: A role of rVLPs has been suggested as a subunit vaccine. NV VLPs produced in plants have undergone a phase I clinical trial in adult volunteers by the oral route, when they were found to be safe and immunogenic (Tacket et al. 2003). Alphavirus vectors, such as Venezuelan equine encephalitis (VEE) (Ball et al. 1999) virus, are also being tried for norovirus vaccine development. If a vaccine is feasible, it could reduce the incidence of epidemic viral gastroenteritis and would be of special importance to military personnel, nursing home residents, and malnourished infants.

\section{Adenovirus}

Adenoviruses were first cultured and reported as distinct viral agents in 1953 when Rowe et al. attempted to establish tissue culture lines from tonsils and adenoidal tissue, surgically removed from children. Similar viral agents were isolated from febrile military personnel with a variety of respiratory illnesses when these were called Acute Respiratory Disease (ARD) agents (Wold and Horwitz 2007). Till date, more than 30 different serotypes have been identified and have shown to cause several clinical syndromes, including upper and lower respiratory tract infections, keratoconjunctivitis, and infantile gastroenteritis.

Structure: Virions are nonenveloped, icosahedral particles, about $70-90 \mathrm{~nm}$ in diameter, and contain a linear 36-kb double-stranded DNA core complex. The outer capsid is composed of 252 capsomeres which are of two main types: hexon capsomeres, 240 in number and form most of the capsid surface, and penton capsomeres, 12 in number, one at each vertex of the icosahedron. Pentons contain a penton base, and a projecting fiber, composed of three domains, an N-terminal domain that binds to the penton base, a central shaft important for infection, and a globular C-terminal knob that binds the primary receptor on host cells. Most of the epitopes recognized by group- and serotype-specific antibodies are present on the hexon and fiber proteins.

Classification: Adenoviruses were first isolated from febrile military personnel with a variety of respiratory illnesses, when they were called ARD agents. Since then, four genera have been identified in adenoviruses that cause infection in a variety of hosts. Human adenoviruses (HAdV) (genus Mastadenovirus) have been classified into six species: A to F. Species $\mathrm{B}$ can be further divided into species B1 and B2. These six species are further divided into 51 
serotypes based on their nucleic acid characteristics and homologies, hexon and fiber protein characteristics, and biologic properties (Jong et al. 1999). Recently, a novel human adenovirus (HAdV) species, the 52nd type, has been characterized which is proposed (Jones 2007).

Different adenoviruses are known to cause a variety of clinical manifestations. Respiratory tract infections are caused by adenoviruses of species $\mathrm{C}, \mathrm{B} 1$, and $\mathrm{E}$; conjunctivitis and pharyngoconjunctival fever by species $\mathrm{C}$ and $\mathrm{Ad} 3$; gastroenteritis by species F (Ad40 and Ad41) and the recently identified Ad52; acute hemorrhagic cystitis by species B2; epidemic keratoconjunctivitis by species D, especially Ad8, Ad19, and Ad37.

Epidemiology: Adenovirus infections occur worldwide and in humans and in a variety of animals. Adenovirus causes $5 \%$ of all infectious diseases in infants and $3 \%$ in the age of 2-4 years (Pacini et al. 1987). It is known that adenovirus is the second common agent in infantile gastroenteritis, after rotavirus (Blacklow and Greenherg 1991). Faeco-oral transmission is the most important route of transmission in young children. Initial spread can occur by the respiratory route, but feces are a more common source of transmission because prolonged secretion after acute infection occurs through the gastrointestinal tract and the virus is shed both during the acute illness and then intermittently thereafter (Fox et al. 1969). Also, these viruses have been reported to be nosocomially transmitted.

The incidence of adenovirus gastroenteritis varies worldwide, an Asian multicentric study has shown that PCR in stool for adenovirus was positive in $4.4 \%$ of pediatric patients with diarrhea ( $\mathrm{Li}$ et al. 2005), and adenovirus was responsible for $12.3 \%$ of cases of diarrhea in Bangladesh outbreak (Jarecki-Khan et al. 1993); for $11.6 \%$ pediatric gastroenteritis cases in Italy (Cevenini et al. 1987) and $2 \%$ cases in Brazil (Filho et al. 2007).

About $80 \%$ of fecal adenoviruses present in faeces of patients with acute gastroenteritis are caused by enteric adenovirus AD 40 and 41, but other serotypes have also been reported to cause gastroenteritis, like Ad9 and Ad10, and were found in Dhaka city, Bangladesh Dey et al. 2009; Ad2, Ad3, Ad8, and Ad31 were found in Japan, Korea, and Vietnam (Li et al. 2005).

HAdV is present with low prevalence throughout the year, with a slight but not significant increase in incidence in late summer and early autumn.

Clinical features: The predominant symptom of infections with enteric adenoviruses is watery diarrhea, with a mean duration of 8.6 days (Ad40) and 12.2 days (Ad41) accompanied by fever and vomiting (Van et al. 1992). Few children with Ad41 infections may experience prolonged symptoms (greater than or equal to 14 days). A low frequency of respiratory symptoms has also been reported (21\%) (Uhnoo 1984). The established adenoviruses may present a different clinical picture, characterized by diarrhea of shorter duration, higher fever, and significantly increased occurrence of respiratory symptoms.

\section{Laboratory Diagnosis}

1. Agglutination Test: For detection of adenovirus proteins in stool, latex agglutination tests are available. Though these tests may be useful for diagnosing enteric adenoviruses, they may give false-positive results with nonenteric adenoviruses and are less sensitive and nonspecific extracts of stool can cause a high number of invalid tests.

2. Electron Microscopy: Noncultivatable enteric adenoviruses can be detected in stool extracts by electron microscopy.

3. ELISA: Few commercial immunoassays are available for the detection of adenovirus antigen in stool samples. It is the test of choice to detect adenoviruses 40 and 41 in stool (Gleaves et al. 1993). Monoclonal antibodies can be used in both ELISA or IF format for differentiating serotypes 40 and 41 from other adenoviruses.

4. Cell Culture: Since enteric adenoviruses are difficult to grow in conventional cell lines used for respiratory adenoviruses, these have 


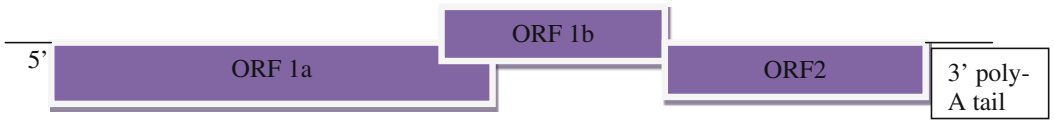

Non Structural Proteins

Structural proteins

Fig. 4.6 Genomic organization of astroviruses. $5^{\prime}$ end and poly A tail are indicated. (Smits et al. 2010), 6.8-kb positive-sense RNA. Expression: subgenomic RNA

been referred to as noncultivatable adenoviruses, though these may be cultivated in alternate tissue culture host cell systems, for example, Graham 293 cells.

5. PCR: Currently, PCR is used for diagnosis, typing, and quantitation of adenovirus infections in stool samples.

Treatment: Generally, it is not required because the disease is often self-limited. No vaccine for enteric adenoviruses is available at present.

\section{Astroviruses}

Astroviruses were first observed by Madeley and Cosgrove in (1975) in stools of infants hospitalized with diarrhea and in outbreaks of gastroenteritis in newborn nurseries (Madeley and Cosgrove 1975). These RNA viruses, together with the Caliciviridae, account for much of the gastroenteritis that had previously been of unknown aetiology and was presumed to be caused by undetected viral agents.

Structure: Astroviruses are $28-30 \mathrm{~nm}$ particles with a smooth margin and a characteristic five- to six-pointed star on the surface (Greek: astron means star) as seen by electron microscope. These are nonenveloped and show icosahedral symmetry. Capsid consists of three proteins of approximately $30 \mathrm{kDa}$ size, which are produced by proteolytic cleavage of a large polypeptide. The genome consists of positivesense, single-stranded RNA of approximately $7.2 \mathrm{~kb}$, is polyadenylated, and has both $5^{\prime}$ and $3^{\prime}$ nontranslated regions (NTR). It contains three ORFs, ORF1a, and ORF1b codes for nonstructural proteins, protease, and the RNA-dependent polymerase, respectively, while ORF2 encodes capsid proteins (Smits et al. 2010) (Fig 4.6). ORF two is translated from a subgenomic RNA and produces a polyprotein which is cleaved by cellular proteases (Macndez and Arias 2007).

Classification: Astroviruses have been isolated from humans and from a variety of animals and birds. Astroviruses are classified into two genera: Mamastrovirus, which infect mammals including humans, and Avastroviruses, which infect avian species. Human astroviruses (HAstVs) have been classified into eight serotypes, 1 to 8 on the basis of immunofluorescence and plaque neutralization assays, and by immunoelectron microscopy using hyperimmune sera against different culture-adapted strains. Genotypes defined by the amino acid sequence of the carboxyl-terminal region of the structural polyprotein correlate well with the eight HAstV serotypes that have been described (Mendez and Arias 2007).Worldwide, serotype 1 is the most common, although the predominant serotypes may vary by region and time (Guix et al. 2005).

Epidemiology: Astroviruses were found in less than $1 \%$ of children with diarrhea when less sensitive assays such as electron microscopy were used for diagnosis. The prevalence increased to 2.5-9\% among patients hospitalized with diarrhea, when more sensitive assays like monoclonal antibody assay, enzyme immunoassays, and real-time PCRs were developed (Glass et al. 1996). Human astrovirus infections occur worldwide (Table 4.8), and infants and young children are most commonly affected, although adult population may also become infected. The incubation period for astrovirus disease is 1-5 days, and illness lasts 1-5 days in the immunocompetent host, although protracted diarrhea has been associated with serotype 3 strains (Caballero et al. 2003). 
Table 4.8 Epidemiological features of astrovirus gastroenteritis outbreaks

\begin{tabular}{llll}
\hline Parameters & Li et al. (2010) & Oh et al. (2003) & Liu et al. (2007) \\
\hline Place of study & Inner Mongolia, China & Germany & Wuhan City, China \\
\hline Time period of study & $\begin{array}{l}\text { 9 October 2008-13 } \\
\text { February 2009 }\end{array}$ & February 2001-January 2002 & June 2004-May 2005 \\
\hline $\begin{array}{l}\text { Setting of outbreak } \\
\text { Nursery in maternity } \\
\text { hospital }\end{array}$ & $\begin{array}{l}\text { Children hospitalized with acute } \\
\text { gastroenteritis }\end{array}$ & $\begin{array}{l}\text { OPD of Wuhan } \\
\text { children's hospital }\end{array}$ \\
\hline $\begin{array}{l}\text { Incidence of } \\
\text { astrovirus }\end{array}$ & $45.90 \%(28 / 61)$ & $4 \%(5 / 129)$ & $9.87 \%(33 / 335)$ \\
$\begin{array}{l}\text { Most common } \\
\text { serotype detected }\end{array}$ & HAst V1b & HAst V1 & HAst V1 \\
\hline
\end{tabular}

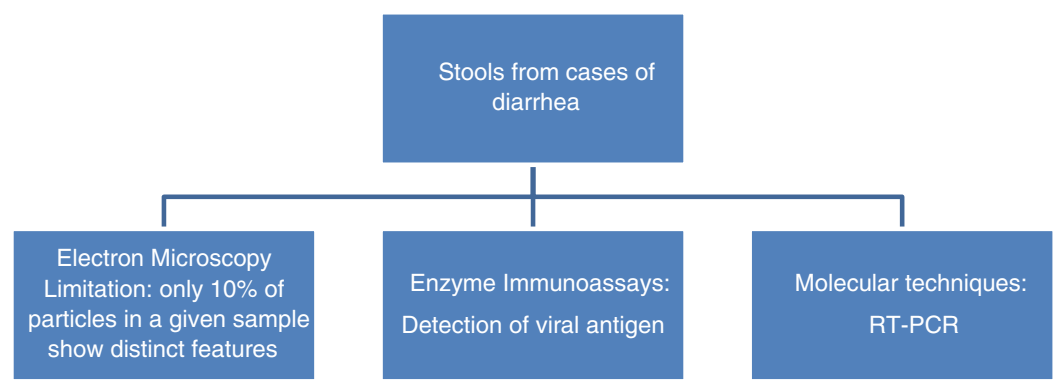

Fig. 4.7 Laboratory diagnosis of astrovirus infection

The main route of transmission of astroviruses is faeco-oral, though person-to-person spread, waterborne spread, and fomites have also been implicated in outbreaks of gastroenteritis.

Pathogenesis: The astroviruses are confined to mature epithelial cells near the villous tip in jejunum. No inflammation is associated with astrovirus infection. HAstVs have the ability to induce apoptosis in cultured cells. Astrovirus infection may result in decreased intestinal disaccharidase activity and subsequent osmotic diarrhea. Many other mechanisms may be used by these viruses to produce the disease.

Clinical features: Watery diarrhea may be associated with vomiting, abdominal pain, and fever. Dehydration may develop in patients with underlying gastrointestinal disease, poor nutritional status, and mixed infection. The incubation period of illness has been estimated to be 3-4 days. Immunocompromised patients such as those with HIV, chronic lymphocytic leukemia, or bone marrow transplant recipients are highly susceptible to infections with HAstV.
Laboratory diagnosis: Shown in Fig. 4.7. Illness associated with these agents is generally self-limited, and if required, treatment is supportive and directed at maintaining hydration and electrolyte balance.

\section{Toroviruses}

Toroviruses are 100-140 nm, enveloped viruses of family Coronaviridae that have a singlestranded, positive-sense linear RNA about $28 \mathrm{~kb}$ in size, capped, and polyadenylated. The tubular nucleocapsid is tightly coiled into an open torus or donut shape and hence the name "torovirus." The particles have a fringe of peplomers on their surface that are about $10 \mathrm{~nm}$ long. The virion RNA is infectious and serves as both the genome and viral messenger RNA. Genomic RNA encodes for ORF1a, and ORF1b is translated by a frame-shifting mechanism. Resulting proteins pp1a and pp1ab are processed into the viral polymerase $(\mathrm{RdRp})$ and other nonstructural 
proteins involved in RNA synthesis. Structural proteins are expressed as subgenomic RNAs.

Replication: cytoplasmic

1. Virus attaches to host receptors through the S-protein and is endocytosed into vesicles in the host cell.

2. Fusion of virus membrane with the vesicle membrane (probably mediated by E2), ssRNA(+) genome, is released into the cytoplasm.

3. Synthesis and proteolysis of replicase polyproteins. Replicase produces the complementary ssRNA(-) first, which will serve as a template for the synthesis of genomic RNA and subgenomic mRNAs.

4. Synthesis of structural proteins encoded by subgenomic mRNAs.

5. Assembly and budding at membranes of the endoplasmic reticulum (ER), the intermediate compartments, and/or the Golgi complex.

6. Release of new virions.

The virus has been associated with gastroenteritis in horses (species Berne virus), cattle (species Breda virus), pig (species equine Torovirus), and probably humans (species Human Torovirus). A study from Canada demonstrated an association between torovirus excretion and nosocomial gastroenteritis in pediatric patients. Toroviruses were identified in $72(35.0 \%)$ of 206 gastroenteritis cases compared with $30(14.5 \%)$ of 206 controls $(\mathrm{P}<0.001)$. Persons infected with torovirus were more frequently immunocompromised and nosocomially infected and experienced less vomiting and more bloody diarrhea than did those with rotavirus or astrovirus infection. An antibody response to torovirus was seen in more than half of the patients with torovirus in stool (Jamieson et al. 1998). Asymptomatic shedding is common, particularly in tropical climates and in populations living in poor hygienic conditions.

Diagnosis: Laboratory diagnosis of the human toroviruses depends entirely on electron microscopy of stool specimens and detection of characteristic particles in negatively stained specimens.

\section{Picobirnavirus}

These viruses are $30-40 \mathrm{~nm}$ in diameter and have icosahedral symmetry with triangulation number ( $\mathrm{T}$ ) equal to 3 . These have a bisegmented, double-stranded RNA, and the length of the two parts of the genome is 1.7 and $2.5 \mathrm{~kb}$. The capsid protein gene is encoded by the second open reading frame of the larger genomic segment (Chandra 1997). Although the virus has been detected mainly from the stools of gastroenteritis patients and several mammals and birds, the pathogenicity of the virus has not been established.

\section{Coronavirus}

Human coronaviruses have occasionally been implicated in enteric disease, particularly in newborns (Gerna et al. 1985). The evidence for human coronavirus in enteric disease is primarily based on visualization of coronavirus-like particles (VLPs) by electron microscopy, plus some reports of isolation of virus from children with enteric disease (Gerna et al. 1985; Payne et al. 1986; Resta et al. 1985). Because other particles in stool specimens (e.g., cellular membranes) can have similar morphology to coronaviruses, electron microscopic detection of coronavirus particles in stools is not diagnostic of infection.

\section{Waterborne Outbreak of Viral Gastroenteritis}

The epidemiologic prototype of viral gastroenteritis outbreaks has been the Norwalk virus infection. In the United States, Norwalk virus has been identified as the cause of $32-42 \%$ of outbreaks of viral gastroenteritis (Hedberg and Osterholm 1993).

Laboratory confirmation of the cause of outbreaks of waterborne viral gastroenteritis requires either the detection of virus in stool or demonstration of a rise in specific antibody. 


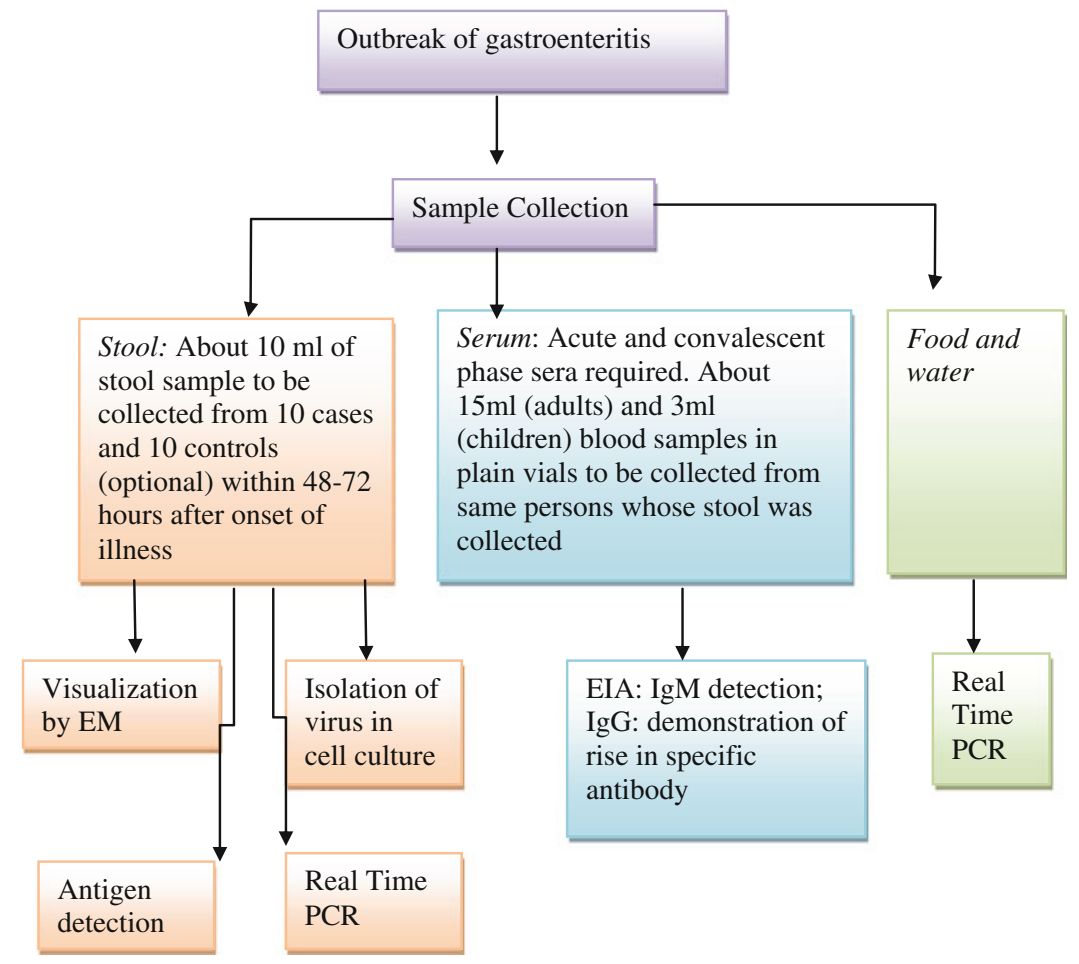

Fig. 4.8 Schematic representation of epidemiologic and laboratory methods for conducting an outbreak investigation. Hedberg and Osterholm (1993)

Algorithm for evaluating outbreaks of viral gastroenteritis is shown in Fig. 4.8. Novel approaches are being developed for syndrome surveillance of acute viral gastroenteritis like development of multiplex real-time reverse transcriptase PCRs (Svraka et al. 2009; Logan 2006).

\section{References}

Adler JL, Zickl R (1969) Winter vomiting disease. J Infect Dis 119:668-673

Atmar RL, Estes MK (2001) Diagnosis of noncultivatable gastroenteritis viruses, the human caliciviruses. Clin Microbiol Rev 14:15-37

Ball JM, Graham DY, Opekun AR et al (1999) Recombinant Norwalk virus-like particles given orally to volunteers: phase I study. Gastroenterology 117:40-48

Barnes GL, Lund JS, Mitchell SV, De Bruyn L, Piggford L, Smith AL, Furmedge J, Masendycz PJ, Bugg HC, Bogdanovic-Sakran N, Carlin JB, Bishop RF (2002)
Early phase II trial of human rotavirus vaccine candidate RV3. Vaccine 20:2950-2956

Blacklow NR, Greenherg HB (1991) Viral gastroenteritis. N Engl J Med 325:252-264

Blacklow NR, Dolin R, Fedson DS, DuPont H, Northrup RS, Hornick RB, Chanock RM (1972) Acute infectious nonbacterial gastroenteritis: etiology and pathogenesis. Annu Intern Med 76:993-1008

Brandt CD, Kim HW, Rodriguez WJ, Arrobio JO, Jeffries BC, Stallings EP, Lewis C, Miles AJ, Chanock RM, Kapikian AZ, Parrott RH (1983) Pediatric viral Gastroenteritis during eight years of study. J Clin Microbiol 18:71-78

Bresee JS, Glass RI, Ivanoff B, Gentsch JR (1999) Current status and future priorities for rotavirus vaccine development, evaluation and implementation in developing countries. Vaccine 17:2207-2222

Caballero S, Guix S, El-Senousy WM, Calico I, Pinto RM, Bosch A (2003) Persistent gastroenteritis in children infected with astrovirus: association with serotype-3 strains. J Med Virol 71:45-50

Cannon RO, Poliner JR, Hirschhorn RB, Rodeheaver DC, Silverman PR, Brown EA, Talbot GH, Stine SE, Monroe SS, Dennis DT, Glass RI (1991) A multistate outbreak of Norwalk virus gastroenteritis associated with consumption of commercial ice. J Infect Dis 164:860-863 
Carlson JA, Middleton PJ, Szymanski MT et al (1978) Fatal rotavirus gastroenteritis: an analysis of 21 cases. Am J Dis 132:477-479

Cevenini R, Mazzaracchio R, Rumpianesi F, Donati M, Moroni A, Sambri V, La Placa M (1987) Prevalence of enteric adenovirus from acute gastroenteritis: a five year study. Eur J Epidemiol 3(2):147-150

Chadwick PR, McCann R (1999) Transmission of a small round structured virus by vomiting during a hospital outbreak of gastroenteritis. J Hosp Infect 26:251-259

Chandra R (1997) Picobirnavirus, a novel group of undescribed viruses of mammals and birds: a minireview. Acta Virologica 41(1):59-62

Chitambar SD, Lahon A, Tatt VS, Maniya NH, Tambe GU, Khatri KI, Desai HS, Ugare MR, Kulkarni SV, Waghmare AP (2011) Occurrence of group B rotavirus infections in the outbreaks of acute gastroenteritis from western India. Ind $\mathbf{J}$ Med Res 134:399-400

De Jong JC, Wermenbol AG, Verweij-Uijterwaal MW, Slaterus KW, Wertheim-Van Dillen P, Van Doornum GJ, Khoo SH, Hierholzer JC (1999) Adenoviruses from human immunodeficiency virus-infected individuals, including two strains that represent new candidate serotypes Ad50 and Ad51 of species B1 and D, respectively. J Clin Microbiol 37:3940-3945

Dennehy PH (2008) Rotavirus Vaccines: an Overview. Clin Microbiol Rev 21(1):198-208

Dey SK, Shimizu H, Phan TG, Hayakawa Y, Islam A, Salim AF, Khan AR, Mizuguchi M, Okitsu S, Ushijima H (2009) Molecular epidemiology of adenovirus infection among infants and children with acute gastroenteritis in Dhaka, Bangladesh. Infect Genet Evol 9(4):518-522

Dolin R, Reichman RC, Roessner KD, Tralka TS, Schooley RT, Gary W, Morens D (1982) Detection by immune electron microscopy of the Snow Mountain agent of acute viral gastroenteritis. J Infect Dis 146:184-189

Dowell SF et al (1995) A multistate outbreak of oyster associated gastroenteritis, implication for interstate tracing of contaminated shellfish. J Infect Dis 171:1497-1503

Estes MK, Kapikian AZ (2007) Rotaviruses. In: Knipe DM, Howley PM (eds) Fields virology, 5th edn. Lippincott Williams and Wilkins, Philadelphia, pp 981-1000

Filho EP, da Costa Faria NR, Fialho AM, de Assis RS, Almeida MM, Rocha M, Galvão M, dos Santos FB, Barreto ML, Leite JP (2007) Adenoviruses associated with acute gastroenteritis in hospitalized and community children up to 5 years old in Rio de Janeiro and Salvador, Brazil. J Med Microbiol 56:313-319

Fox JP, Brandt CD, Wassermann FE et al (1969) The virus watch program: a continuing surveillance of viral infections in metropolitan New York families.VI. Observations of adenovirus infections: virus excretion patterns, antibody response, efficiency of surveillance, patterns of infections, and relation to illness. Am J Epidemiol 89:25-50
Gerna G, Passarani N, Battaglia M, Rondanelli EG (1985) Human enteric coronaviruses: antigenic relatedness to human coronavirus OC43 and possible etiologic role in viral gastroenteritis. J Infect Dis 151:796-803

Gilger MA, Matson DO, Conner ME, Rosenblatt HM, Finegold MJ, Estes MK (1992) Extraintestinal rotavirus infections in children with immunodeficiency. J Pediatr 120:912-917

Glass RI, Noel J, Mitchell D, Herrmann JE, Blacklow NR, Pickering LK, Dennehy P, Ruiz Palacios G, de Guerrero ML, Monroe SS (1996) The changing epidemiology of astrovirus-associated gastroenteritis: a review. Arch Virol 12:287-300S

Glass RI, Bhan MK, Ray P et al (2005) Development of candidate rotavirus vaccines derived from neonatal strains in India. J Infect Dis 192(1):S30-S35

Gleaves CA, Militoni J, Ashley RL (1993) An enzyme immunoassay for the direct detection of adenovirus in clinical specimens. Diagn Microbiol Infect Dis 17:57-59

Graham DY, Jian X, Tanaka T et al (1994) Norwalk virus infection of volunteers: new insights based on improved assays. J Infect Dis 170:34

Guerrant RL, Hughes JM, Lima NL, Crane J (1990) Diarrhea in developed and developing countries: magnitude, special settings, and etiologies. Rev Infect Dis 12:S41-S45

Guix S, Bosch A, Pinto RM (2005) Under the microscope. Human astrovirus diagnosis and typing: current and future prospects. Lett Appl Microbiol 41:103-105

Hafliger D, Hubner PH, Luthy J (2000) Outbreak of viral gastroenteritis due to sewage contaminated drinking water. Int J Food Microbiol 54:123-126

Hedberg CW, Osterholm MT (1993) Outbreaks of foodborne and waterborne viral gastroenteritis. Clin Microbiol Rev 6(3):199-210

Hung T (1988) Rotavirus and adult diarrhea. Adv Virus Res 135:193-218

Hutson AM, Atmar RL, Graham DY et al (2002) Norwalk virus infection and disease is associated with $\mathrm{ABO}$ histo-blood group type. J Infect Dis 185:1335-1337

II Jones MS, Harrach B, Ganac RD, Gozum MM, Dela Cruz WP, Riedel B, Pan C, Delwart EL, Schnurr DP (2007) New adenovirus species found in a patient presenting with gastroenteritis. J Virol 81:5978-5984

Jamieson FB, Wang EEL, Bain C, Good J, Duckmanton L, Petric M (1998) Human Torovirus: a new nosocomial Gastrointestinal Pathogen. J Infect Dis 178(5):1263-1269

Jarecki- Khan K, Tzipori SR, Unicomb LE (1993) Enteric adenovirus infection among infants with diarrhea in rural Bangladesh. J Clin Microbiol 31:484-489

Jiang X, Wang M, Wang K et al (1993) Sequence and genomic organization of Norwalk virus. Virology 195:51-61

Jones MS, Kapoor A, Lukashov VV, Simmonds P, Hecht F, Delwart E (2005) New DNA viruses identified in 
patients with acute viral infection syndrome. J Virol 79:8230-8236

Kapikian AZ, Wyatt RG, Dolin R, Thornhill TS, Kalica AR, Chanock RM (1972) Visualization by immune electron microscopy of a $27 \mathrm{~nm}$ particle associated with acute infectious nonbacterial gastroenteritis. J Virol 10:1075-1081

Kapikian AZ, Hoshino Y, Chanock RM, Perez-Schael I (1996) Efficacy of a quadrivalent rhesus rotavirusbased human rotavirus vaccine aimed at preventing severe rotavirus diarrhea in infants and young children. J Infect Dis 174(Suppl. 1):S65-S72

Kelkar SD, Zade JK (2004) Group B rotaviruses similar to strain CAL-1, have been circulating in Western India since 1993. Epidemiol Infect 132:745-749

Kukkula M, Arstila P, Klossner ML, Maunula L, Bonsdorff CH, Jaatinen P (1997) Waterborne outbreak of viral gastroenteritis. Scand J Infect Dis 29(4):415-418

Lew JF, Kapikian AZ, Valdesuso J et al (1994) Molecular characterization of the Hawaii virus and other Norwalk-like viruses: evidence for genetic polymorphism among human caliciviruses. J Infect Dis 170:535-542

Li L, Phan TG, Nguyen TA et al (2005) Molecular epidemiology of adenovirus infection among pediatric population with diarrhea in Asia. Microbiol Immunol 49:121-128

Li CY, Liu N, Guo WD, Yu Q, Wang WR, Song ZZ, Yan H, Luo Y, Lu AT, Li HY, Zhu L, Duan ZJ (2010) Outbreak of Neonatal gastroenteritis associated with Astrovirus Serotype 1 at a Hospital in Inner Mongolia, China. J Clin Microbiol 48(11):4306-4309

Li CSY, Paul KS, Tang CJW (2009) Prevalence of diarrhea viruses in hospitalized children in Hong Kong in 2008. J Med Virol 81(11):1903-1911

Liu MQ, Yang BF, Peng JS, Zhou DJ, Tang L, Wang B, Liu Y, Sun SH, Ho WZ (2007) Molecular epidemiology of Astrovirus infection in infants in Wuhan, China. J Clin Microbiol 45:1308-1309

Logan C, O’Leary JJ, O'Sullivan N (2006) Real-time reverse transcription-PCR for detection of rotavirus and adenovirus as causative agents of acute viral gastroenteritis in children. $\mathbf{J}$ Clin Microbiol 44(9):3189-3195

Lopman BA, Reacher MH, van Duijnhoven Y, Hanon FX, Brown D, Koopmans M (2003) Viral gastroenteritis outbreaks in Europe, 1995-2000. Emerg Infect Dis 9(1):90-96

Macndez E, Arias CF (2007) Astroviruses. In: Knipe DM, Howley PM (eds) Fields virology, 15th edn. Lippincott Williams and Wilkins, Philadelphia, pp 981-1000

Madeley CR, Cosgrove BP (1975) Viruses in infantile gastroenteritis (letter). Lancet 2(7925):124

Mendez E, Arias CF (2007) Astroviruses. In: Knipe DM, Howley PM (eds) Fields Virology, 5th edn. Lippincott Williams and Wilkins, Philadelphia, pp 981-1000
Mendez E, Lopez S, Cuadras MA, Romero P, Arias CF (1999) Entry of rotaviruses in is a multistep process. Virology 263:450-459

Midthun K, Greenberg HB, Hoshino Y et al (1985) Reassortant rotaviruses as potential live rotavirus vaccine candidates. J Virol 53:949-954

Nelson EAS, Bresee JS, Parashar UD, Widdowson M-A, Glass RI (2008) Rotavirus epidemiology: the Asian Rotavirus surveillance network. Vaccine 26:3192-3196

Nguyen TA, Yagyu F, Okame M, Phan TG, Trinh QD, Yan H, Hoang KT, Cao AT, Le Hoang P, Okitsu S, Ushijima H (2007) Diversity of viruses associated with acute gastroenteritis in children hospitalized with diarrhea in Ho Chi Minh City. Vietnam. J Med Virol 79:582-590

Oh DY, Gaedicke G, Schreier E (2003) Viral agents of acute gastroenteritis in German children: prevalence and molecular diversity. J Med Virol 71:82-93

Okhuysen PC, Jiang X, Ye L et al (1995) Viral shedding and fecal $\mathrm{IgA}$ response after Norwalk virus infection. J Infect Dis 171:566-569

Oseto M, Yamashita Y, Hattori M, et al. (1993) Successful propagation of human group $\mathrm{C}$ rotavirus in a continuous cell line and characterization of the isolated virus. In: Abstracts of 27th joint viral diseases meeting of the US-Japan cooperative medical sciences program, pp 46-46

Pacini DL, Collier AM, Henderson FM (1987) Adenovirus infections and respiratory illnesses in children in group day care. J Infect Dis 156:920-926

Patel MM, Hall AJ, Vinje J et al (2009) Noroviruses: a comprehensive review. J Clin Virol 44:1-8

Payne CM, Ray CG, Borduin V, Minnich LL, Lebowitz MD (1986) An eight-year study of the viral agents of acute gastroenteritis in humans: ultrastructural observations and seasonal distribution with a major emphasis on coronavirus-like particles. Diagn Microbiol Infect Dis 5:39-54

Prasad BVV, Rothnagel R, Jiang X, Estes MK (1994) Three dimensional structure of baculovirus-expressed Norwalk virus capsids. J Virol 68:5117-5125

Resta S, Luby J, Rosenfeld C, Siegel J (1985) Isolation and propagation of a human enteric coronavirus. Science 229:978-981

Rippey SR (1994) Infectious diseases associated with molluscan shellfish consumption. Clin Microbiol Rev 7:419-425

Sanekata T, Ahmed MU, Kader A et al (2003) Human group B rotavirus infections cause severe diarrhea in children and adults in Bangladesh. J Clin Microbiol 41:2187-2190

Santos N, Hoshino Y (2005) Global distribution of rotavirus serotypes/genotypes and its implication for the development and implementation of an effective rotavirus vaccine. Rev Med Virol 15:29-56

Smits SL, van Leeuwen M, van der Eijk AA, Fraaij PLA, Escher JC, Simon JH, Albert D, Osterhaus ME (2010) Human astrovirus infection in a patient with 
new-onset celiac disease. J Clin Microbiol 48(9):3416-3418

Svraka S, van der Veer B, Duizer E, Dekkers J, Koopmans M, Vennema H (2009) Novel approach for detection of enteric viruses to enable syndrome surveillance of acute viral gastroenteritis. J Clin Microbiol 47:1674-1679

Tacket CO, Sztein MB, Losonsky GA et al (2003) Humoral, mucosal, and cellular immune responses to oral Norwalk virus-like particles in volunteers. Clin Immunol 108:241-247

Tang B, Gilbert JM, Matsui SM, Greenberg HB (1997) Comparison of the rotavirus gene 6 from different species by sequence analysis and localization of subgroup specific epitopes using site directed mutagenesis. Virology 237:89-96

Thornhill TS, Wyatt RG, Kalica AR, Dolin R, Chanock RM, Kapikian AZ (1977) Detection by immune electron microscopy of 26-27 nm virus-like particles associated with two family outbreaks of gastroenteritis. J Infect Dis 135:20-27

Uhnoo I, Wadell G, Svensson L, Johansson ME (1984) Importance of enteric adenoviruses 40 and 41 in acute gastroenteritis in infants and young children. J Clin Microbiol 20(3):365-372
Van R, Wun CC, O'Ryan ML et al (1992) Outbreaks of human enteric adenovirus types 40 and 41 in Houston day care centres. J Pediatr 120:516-521

Vega E, Barclay L, Gregoricus N, Williams K, Lee D, Vinjé J (2011) Novel surveillance network for norovirus gastroenteritis outbreaks, United States. Emerg Infect Dis 17(8):1389-1395

Werber SD, Laus Evic D, Mugos B, Vratnic Z, IvanovicNikolic L, Alexandre-Bird A, Fiore L, Ruggeri FM, Di Bartolo I, Battistone A, Gassilloud B, Perelle S, Nitzan Kaluski D, Kivi M, Andraghetti R, Pollock KGJ (2009) Massive outbreak of viral gastroenteritis associated with consumption of municipal drinking water in a European capital city. Epidemiol Infect 137:1713-1720

Wilde J, Van R, Pickering L et al (1992) Detection of rotaviruses in the day care environment by reverse transcriptase polymerase chain reaction. J Infect Dis 166:507-511

Wold WSM, Horwitz MS (2007) Adenoviruses. In: Knipe DM, Howley PM (eds) Fields cirology, 5th edn. Lippincott Williams and Wilkins, Philadelphia, pp 981-1000 